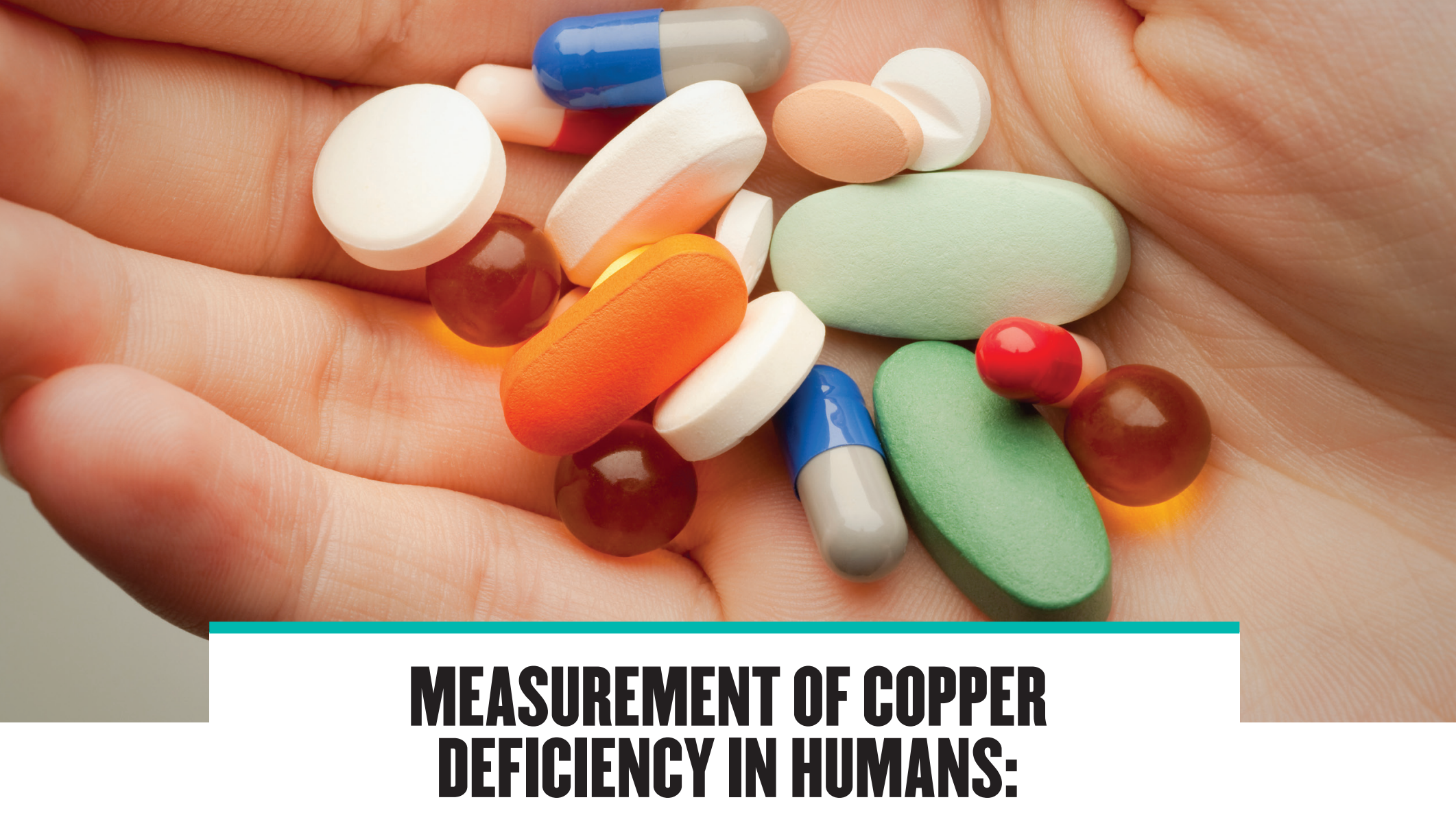

\title{
CCS as a Novel Biomarker of Copper Status in Bariatric Surgery Patients
}

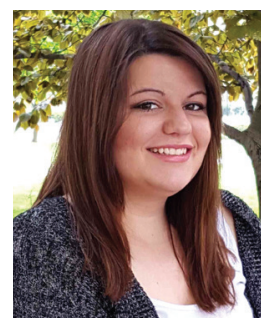

Emily Watson is a senior majoring in nutrition science at Purdue University with a minor in biology. She spent two years in Dr. GletsuMiller's lab where she completed an honors thesis and was part of the Transdisciplinary Obesity Prevention Research Science (TOPRS) program. Upon graduation she will continue doing research under a pediatric endocrinologist at the Indiana School of Medicine. She plans to attend medical school in the future.

\section{Mentor}

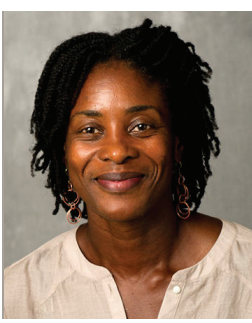

Nana Gletsu-Miller is currently an assistant professor of nutrition science at Purdue University. She obtained a $\mathrm{PhD}$ in nutrition and metabolism from the University of Alberta in Edmonton, Canada, in 1998. Her dissertation studies involved the effect of obesity on insulin signal transduction in the cell nucleus. Thereafter she was a postdoctoral fellow in the Department of Pathology at Emory University, Atlanta, with Kenneth Bernstein, studying the transcriptional regulation of angiotensin converting enzyme. In 2002 she transitioned to focus on human studies in the field of bariatric surgery, in the Department of Surgery, Emory University, as a research instructor. In 2006 she became an assistant professor of research in surgery in the Hubert Department of Global Health. Her studies focused on the mechanisms responsible for resolution of type 2 diabetes following bariatric surgery Gletsu-Miller joined the Department of Nutrition Science at Purdue in 2011. Her studies investigate the nutritional status of bariatric surgery patients and focus on deficiencies in iron, copper, vitamin $\mathrm{D}$, and essential fatty acids. 


\section{Abstract}

Bariatric surgery is a popular and effective treatment for obesity. However, an unfavorable consequence for patients who have had bariatric surgery is copper $(\mathrm{Cu})$ deficiency. Current screening methods used for $\mathrm{Cu}$ deficiency are neither sensitive nor specific enough to diagnose $\mathrm{Cu}$ deficiency or detect changes in $\mathrm{Cu}$ status. The purpose of this research is to determine if concentrations of copper chaperone for superoxide dismutase (CCS) in erythrocytes are associated with serum $\mathrm{Cu}$ concentrations in bariatric surgery patients, by assessing whether changes in CCS concentrations can be observed in response to altering $\mathrm{Cu}$ status when patients are supplemented with $\mathrm{Cu}(8 \mathrm{mg} /$ day $)$ or iron $(\mathrm{Fe})(195 \mathrm{mg} /$ day $)$ for 8 weeks. Blood samples were obtained from subjects who had undergone bariatric surgery and serum $\mathrm{Cu}$ concentrations were measured. Concentrations of CCS in erythrocytes were measured using Western blotting. CCS and serum $\mathrm{Cu}$ were not significantly correlated $(p>0.05)$, though there were significant increases in CCS for patients supplemented with $\mathrm{Fe}(p<0.05)$. This indicates that CCS increases as a result of Fe supplementation. Because serum $\mathrm{Cu}$ and erythrocyte CCS were not significantly correlated, it is unclear if CCS is representative of $\mathrm{Cu}$ status. Future research should focus on improving the reliability of the methods and increasing the sample size.

Watson, E. (2016). Measurement of copper deficiency in humans: CCS as a novel biomarker of copper status in bariatric surgery patients. Journal of Purdue Undergraduate Research, 6, 64-72. http://dx.doi.org/10.5703/1288284316156

\section{Keywords}

bariatric surgery, copper, biomarker, CCS, supplements, nutrient deficiency, humans, trace minerals, iron, Western blot

\section{LITERATURE REVIEW AND RATIONALE}

Obesity is a rising epidemic in the United States, affecting $35 \%$ of adults (body mass index, BMI $\geq$ $30 \mathrm{~kg} / \mathrm{m}^{2}$ ), with $4.5 \%$ of men and $8 \%$ of women being severely obese (BMI $\geq 40 \mathrm{~kg} / \mathrm{m}^{2}$ ) (Flegal, Carroll, Kit, \& Ogden, 2012). It is forecasted that incidence of moderate $\left(B M I \geq 35 \mathrm{~kg} / \mathrm{m}^{2}\right)$ and severe obesity will continue to increase in the United States (Finkelstein et al., 2012). Obesity is a major risk factor for several chronic diseases, including diabetes, cardiovascular disease, and cancer (WHO, 2016). For those patients who wish to lose weight, there are several methods that can be used to induce weight loss, including diet, exercise, medication, and surgery.

Bariatric surgery is considered to be one of the most effective treatments for obesity and is recommended for individuals who are moderately or severely obese, suffer from an obesity-related health condition, and have not responded to other methods of weight loss (Jensen et al., 2014; Sjöström et al., 2004). On average, a patient's BMI drops between $8-10$ units $\left(\mathrm{kg} / \mathrm{m}^{2}\right)$, with maximum weight loss 12 months post-surgery (Schauer et al., 2014). Bariatric surgery is also very popular; in $2013,154,276$ people with severe obesity in the U.S. underwent the procedure (Angrisani et al., 2015).

There are multiple types of bariatric surgery procedures. Of those, Roux-en-Y gastric bypass (RYGB), seen in Figure 1A, used to be the most commonly performed bariatric surgery procedure, but is currently declining in popularity (Angrisani et al., 2015). In the RYGB surgery, the duodenum of the small intestine and most of the stomach is bypassed, leaving a $30 \mathrm{~mL}$ stomach pouch (MacLean, Rhode, $\&$ Nohr, 2000). This procedure induces weight loss through food restriction and nutrient malabsorption (Gletsu-Miller \& Wright, 2013). Another type of bariatric surgery procedure is the sleeve gastrectomy (SG) surgery, seen in Figure 1B, which is currently the most popular type of bariatric surgery procedure. In this procedure, the surgeon removes a portion of the stomach but leaves the intestines intact. This induces weight loss through food restriction (GletsuMiller \& Wright, 2013).

There are many documented benefits of receiving bariatric surgery. These benefits include resolution or improvement of diseases, such as type 2 diabetes, cardiometabolic disease, hypertension, depression, and reduction in mortality rates (Adams et al., 2012; Christou et al., 2004; Dixon et al., 2008; Schowalter et al., 2007; Sjöström et al., 2007; Sjöström et al., 2012). However, there are also some negative 

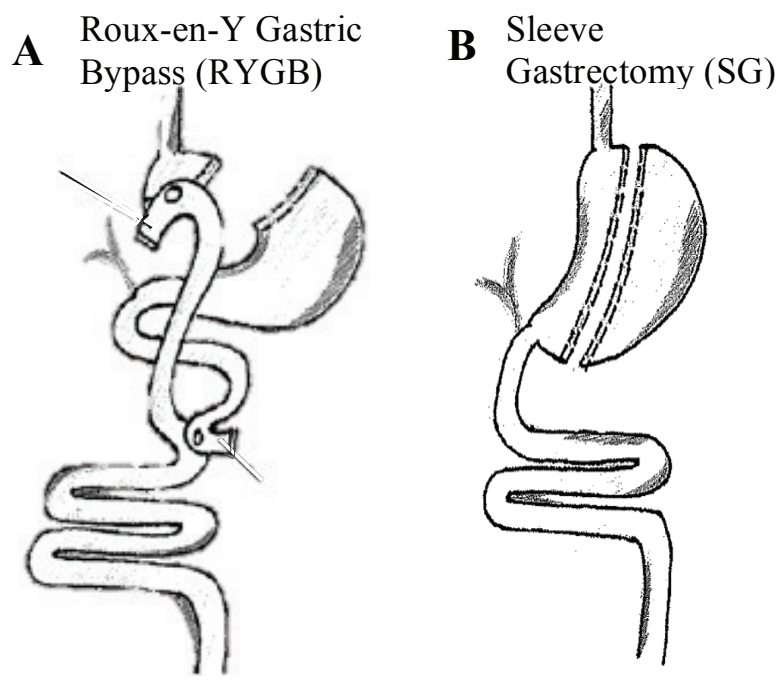

Figure 1. Depiction of two common bariatric surgery types.

consequences associated with undergoing bariatric surgery. Bariatric surgery alters dietary intake and nutrient absorption, which may result in nutritional deficiencies following surgery (Gletsu-Miller \& Wright, 2013). Some of the nutritional complications are wellknown and screened for by health care providers, including malnutrition of protein, vitamin B12, vitamin $\mathrm{D}$, calcium, and iron (Fe). Others that are not typically screened for by physicians include B vitamins, fatsoluble vitamins, and minerals such as copper $(\mathrm{Cu})$ and zinc (Clements et al., 2006; Gasteyger, Suter, Gaillard, $\&$ Giusti, 2008). Without screening, patients who have undergone bariatric surgery are at risk for postsurgical nutrient deficiencies that are not being monitored or treated appropriately.

As one of the essential minerals, Cu plays many important roles in the body by acting as a cofactor for the enzyme function of ceruloplasmin (Cp) and superoxide dismutase 1 (SOD1) (Homberg \& Laurell, 1947). It also assists in hemoglobin formation, cell signaling, and cellular respiration (Fox, 2003; Haremaki Fraser, Kuo, Baron, \& Weinstein, 2007). Dietary $\mathrm{Cu}$ requirements are met by most healthy adults, because it is found in commonly consumed foods such as mushrooms, leafy green vegetables, and even cocoa (Trumbo, Yates, Schlicker, \& Poos, 2001). However, cases of $\mathrm{Cu}$ deficiency have been found as a result of bariatric surgery. $\mathrm{Cu}$ is absorbed mostly in the duodenum of the small intestine, which is bypassed in patients who have had the RYGB procedure (Mason, 1979). A previous study reported from our group determined that incidence of copper deficiency following RYGB surgery was 18.8\% (Gletsu-Miller et al., 2012).

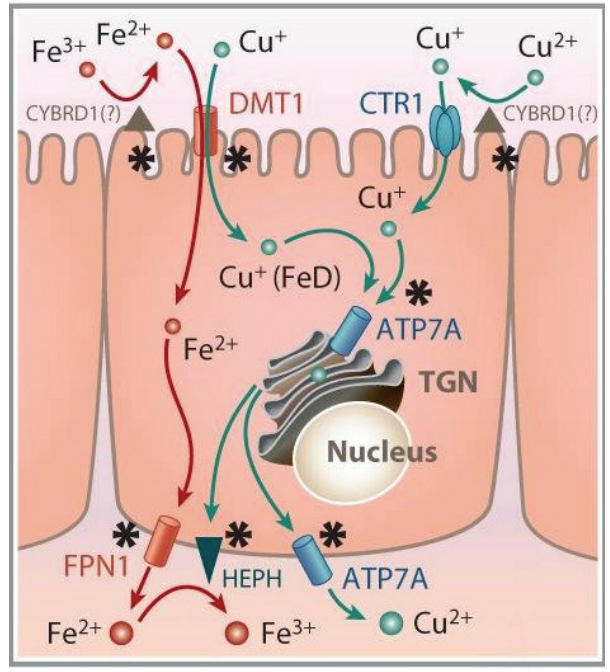

Figure 2. Fe and $\mathrm{Cu}$ interaction in the duodenal epithelium. $\mathrm{Cu}$ and Fe can both be absorbed into the enterocyte through DMT1. Additionally, they both compete for reduction through CYBRD1. ATP7A is a $\mathrm{Cu}$ transporter that is upregulated during Fe deficiency (Gulec \& Collins, 2014). Copper transporter 1 (Ctrl), transgolgi network (TGN), ferroportin 1 (FPN1), hephaestin (HEPH).

One way $\mathrm{Cu}$ status can be altered is through interactions with Fe. A notable site of interaction between $\mathrm{Fe}$ and $\mathrm{Cu}$ is the divalent metal-ion transporter 1 (DMT1), a transporter on the basolateral membrane of the enterocyte, where they compete for absorption (Gulec \& Collins, 2014). In addition, both minerals need to be in their reduced forms to be absorbed into the enterocyte, thus they compete for reduction by cytochrome $\mathrm{B}$ reductase 1 (CYBRD1). Previous studies have shown that high dietary $\mathrm{Fe}$ results in decreased $\mathrm{Cu}$ status in rats (Jung-Heun Ha, Zhao, Wang, Flores, \& Collins, 2016). Copper-transporting ATPase 1 (ATP7A) is the primary transporter of $\mathrm{Cu}$ and is upregulated during $\mathrm{Fe}$ deficiency, and is believed to also influence $\mathrm{Fe}$ transport (Collins, Franck, Kowdley, \& Ghishan, 2005). Duodenal epithelial interactions are shown in Figure 2 (Guelc \& Collins, 2014). One additional interaction that should be noted is Cu's function in Fe homeostasis. $\mathrm{Cp}, \mathrm{a} \mathrm{Cu}$ binding molecule, mediates Fe release from sites of $\mathrm{Fe}$ storage and into the blood for Fe to perform essential functions (Hellman \& Gitlin, 2002).

Currently, there are several methods of assessing $\mathrm{Cu}$ status. These methods include measuring concentrations of erythrocyte SOD1, plasma Cp activity, serum $\mathrm{Cu}$, or liver $\mathrm{Cu}$ (Danzeisen et al., 2007). SOD1 has not been found to be a reliable or 
sensitive indicator for $\mathrm{Cu}$ status because erythrocyte concentrations of SOD1 are affected by a variety of health and stress conditions (Danzeisen et al., 2007). $\mathrm{Cp}$ decreases during severe $\mathrm{Cu}$ deficiency but is also an acute-phase response protein that increases during inflammation and infection (Danzeisen et al., 2007). This may result in falsely elevated concentrations of $\mathrm{Cp}$ that could misrepresent $\mathrm{Cu}$ status. Serum $\mathrm{Cu}$ is tightly regulated but can also be elevated during inflammation; thus, it does not accurately correspond to $\mathrm{Cu}$ status (Danzeisen et al., 2007). Liver $\mathrm{Cu}$ is the only reliable $\mathrm{Cu}$ status indicator; however, it is difficult to measure in humans without an invasive procedure (Araya et al., 2003). Thus, there is a critical need for a more sensitive and specific biomarker to assess $\mathrm{Cu}$ deficiency and changes in humans.

Studies have shown that copper chaperone for superoxide dismutase (CCS) could be a promising biomarker for assessing $\mathrm{Cu}$ status. CCS plays an important role in delivering $\mathrm{Cu}$ to the antioxidant enzyme SOD1 (Culotta et al., 1997). It was found in rats that CCS expression is more sensitive to mild reductions in $\mathrm{Cu}$ status compared to serum $\mathrm{Cu}$, SOD1, and $\mathrm{Cp}$ activity (Iskandar et al., 2005). $\mathrm{CCS}$ is elevated in the erythrocytes of $\mathrm{Cu}$-deficient rats and mice compared to rats and mice that are normal in $\mathrm{Cu}$ status, reflecting a negative correlation between CCS and serum $\mathrm{Cu}$ (West \& Prohaska, 2004). Since previous animal models show that CCS is a promising biomarker for $\mathrm{Cu}$ status, we would like to look at this in human subjects. In this study, we tested CCS as a biomarker of $\mathrm{Cu}$ status in bariatric surgery patients. We hypothesized that $\mathrm{CCS}$ would respond to changes in $\mathrm{Cu}$ status in $\mathrm{Cu}$-deficient patients supplemented with copper, where CCS was hypothesized to decrease, and when altering $\mathrm{Cu}$ status in response to high doses of $\mathrm{Fe}$ supplementation, where CCS was hypothesized to increase.

\section{OBJECTIVE}

The purpose of my research is to determine whether concentrations of CCS in erythrocytes are associated with serum concentrations of $\mathrm{Cu}$ in patients who have had bariatric surgery. We will additionally determine whether we can observe changes in CCS concentrations in erythrocytes in response to changes in $\mathrm{Cu}$ status by supplementing patients with high doses of $\mathrm{Cu}$ and $\mathrm{Fe}$. We expect CCS to increase for patients supplemented with Fe and decrease for patients supplemented with $\mathrm{Cu}$. From this data, we can evaluate whether CCS would be a viable biomarker to test $\mathrm{Cu}$ status.

\section{METHODS}

\section{Human Subjects}

The Purdue Institutional Review Board approved this study (\#1410015305). Postcards were used to recruit patients who might be eligible for the study. We also used a recruitment service called ResNet, which is a database of patients who are receiving services through the Indiana University Health System. To qualify for the study, subjects must have been female, have had RYGB or SG bariatric surgery at least 6 months prior to enrollment, and have been at least 18 years of age. All subjects gave informed consent to participate in the study. Subjects were excluded if they were pregnant, had received intravenous (IV) Fe in the last month, or had surgical revisions to bariatric surgery. Men were excluded from the study because it is less common for men to undergo bariatric surgery (Buchwald \& Oien, 2013).

\section{Screening}

To enroll in the study, patients had to qualify at a screening visit. Patients filled out three-day food logs before coming in for their screening visits. At the visit, a blood draw was performed in the morning after the patient had undergone an 8-hour overnight fast. Status of $\mathrm{Fe}$ and $\mathrm{Cu}$ were measured by Mid America Clinical Laboratories (MACL, Indianapolis, IN), a commercial reference laboratory. Information was collected regarding demographics and relevant medical history during an interview. Height and weight were also measured at the patient screening visit.

To enroll in the Fe supplementation intervention, patients had to have Fe deficiency based on two or more of the following criteria: ferritin $<20 \mathrm{mcg} / \mathrm{L}$, total iron binding capacity $(\mathrm{TIBC})>370 \mathrm{mcg} / \mathrm{dL}$, soluble transferrin receptor $(\mathrm{sTfR})>2012 \mathrm{mcg} / \mathrm{L}$, and sTfR: ferritin ratio > 500 (Grant et al., 2012). In order to enroll in the $\mathrm{Cu}$ supplementation intervention, patients must have had $\mathrm{Cu}$ deficiency at two separate screening visits, diagnosed by having a serum $\mathrm{Cu}$ concentration $<70 \mathrm{mg} / \mathrm{dL}$ and $\mathrm{Cp}$ activity in plasma $<62.5$ units/L (Gletsu-Miller et al., 2012).

\section{Intervention}

We enrolled one patient into the $\mathrm{Cu}$ supplementation intervention and five patients into the Fe supplementation intervention. We provided patients who were enrolled in the Fe supplementation intervention with Nature Made ferrous sulfate Fe supplementation at a dose of $65 \mathrm{mg}$ taken three times 
a day as recommended by the bariatric surgery guidelines (Mechanick et al., 2013). They received supplementation for 8 weeks with visits at weeks one, two, four, and eight. We provided the patient who enrolled in $\mathrm{Cu}$ intervention $\mathrm{Cu}$ gluconate supplementation from GNC at a dose of $8 \mathrm{mg} /$ day for 8 weeks as previously determined by Griffith and colleagues (2009).

At each study visit, enrolled patients went to the Purdue Clinical Research Center after having undergone an 8-hour overnight fast to have their blood drawn. Supplements were provided at each visit. Controls for this study were bariatric surgery patients who had undergone screening for $\mathrm{Fe}$ and $\mathrm{Cu}$ deficiency but were not deficient.

\section{Fractionation of Erythrocytes}

A blood draw was obtained at all visits for both screened and enrolled patients. The blood was fractionated to separate erythrocytes, monocytes, and plasma as previously described (Araya et al, 2012). Measurements of serum $\mathrm{Cu}$ were measured as described (Lassi \& Prohaska, 2012).

\section{Western Blotting}

Western blotting assays were performed using patients' blood erythrocytes to test for presence of CCS as described by Lassi and Prohaska (2012). We did not regulate protein loading due to difficulty quantifying erythrocyte proteins. Primary antibody, mouse anti-rabbit polyclonal antibody against CCS, was obtained from West and Prohaska (2004), and diluted 1:500. Secondary antibody was obtained from Li-Cor diluted 1:10,000. Positive controls were run on every Western performed. We assessed CCS in all patients who were screened regardless of whether they were $\mathrm{Cu}$-deficient or not. By assessing all patients, we were able to determine normal reference levels of CCS.

\section{STATISTICS AND DATA ANALYSIS}

All data is presented as median values and interquartile (IQ) ranges, unless otherwise specified on the figure. Serum $\mathrm{Cu}$ and erythrocyte CCS correlations were performed using Spearman correlations for non-parametric data. Two outliers were removed from the data before running the statistical measures. A dependent sample T-test was performed to compare changes in the $\mathrm{Fe}$ supplemented patients' concentrations of CCS at visit 1 to those of visit 4. Coefficients of variation (CV) for Western blots were calculated based on positive control samples run for both intraday variation and interday variation.

\section{RESULTS}

\section{Patient Characteristics}

Table 1 shows the patient demographics and characteristics of all screened subjects. We screened 32 subjects; all screened subjects were female. The median age of the study population was 46 years old. Most subjects self-identified as Caucasian (94\%). Their BMIs ranged from 22.3 to $55.9 \mathrm{~kg} / \mathrm{m}^{2}$. Most subjects underwent the RYGB surgery ( $94 \%)$, but one subject had undergone the SG.

\begin{tabular}{|c|c|}
\hline $\begin{array}{l}\text { All Screened Patients } \\
\qquad(\mathrm{N}=32)\end{array}$ & $\begin{array}{c}\text { Median } \\
\text { (Interquartile Range) }\end{array}$ \\
\hline \multicolumn{2}{|c|}{ Demographics } \\
\hline Age (years) & 46 (39-49) \\
\hline $\begin{array}{l}\text { Sex of subject, } \\
\text { female } N(\%)\end{array}$ & $100 \%$ \\
\hline $\begin{array}{l}\text { Race/ethnicity (\%) } \\
\text { CA, AA, HI }\end{array}$ & $94,3,3$ \\
\hline $\begin{array}{l}\text { Type of surgery, } \\
\text { RYGB N (\%) }\end{array}$ & $31(94)$ \\
\hline Years since surgery & $6.82(3.5-10.16)$ \\
\hline \multicolumn{2}{|c|}{ Anthropometrics } \\
\hline BMI $\left(\mathrm{kg} / \mathrm{m}^{2}\right)$ & $30.5(26.8-36.8)$ \\
\hline \multicolumn{2}{|c|}{ Nutritional Status } \\
\hline Serum Cu ( $\mu \mathrm{g} / \mathrm{dL})$ & $109(96-124.5)$ \\
\hline Ferritin $(\mu \mathrm{g} / \mathrm{L})$ & $13.75(6.4-43.78)$ \\
\hline
\end{tabular}

CA: Caucasian; AA: African American; HI: Hispanic; BMI: body mass index.

Table 1. Screened patient characteristics. 


\section{Associations Between Erythrocyte CCS and Serum Cu Concentration}

For the CCS assay, the intraday CV was found to be $16.1 \%$ and the interday $\mathrm{CV}$ was found to be $18.25 \%$. All screened patients were used to assess the association between erythrocye CCS and serum $\mathrm{Cu}$. Figure 3 shows the association between the two measures. It was found that $\mathrm{CCS}$ and serum $\mathrm{Cu}$ were not significantly correlated $(p=0.61)$.

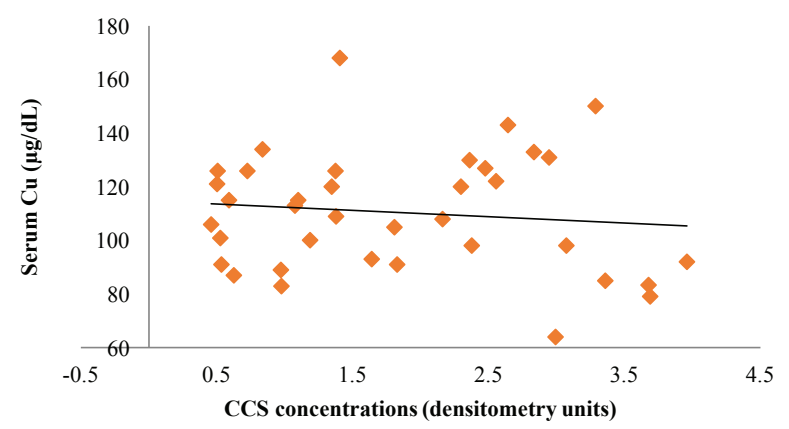

Figure 3. CCS and serum Cu were found not to be significantly correlated. $R=-0.092, p=0.61$.

\section{Impact of $\mathrm{Cu}$ and Fe Supplementation on Erythrocyte CCS Concentrations}

The patient supplemented with $\mathrm{Cu}$ had a BMI of $22 \mathrm{~kg} / \mathrm{m}^{2}$. The patient had a serum $\mathrm{Cu}$ concentration of $79.1 \mu \mathrm{g} / \mathrm{dL}$ on visit 1 and $83.4 \mu \mathrm{g} / \mathrm{dL}$ on visit 4 . Figure 4 shows the serum $\mathrm{Cu}$ concentrations of the patient supplemented with $\mathrm{Cu}$ gluconate $(8 \mathrm{mg} /$ day) for 8 weeks, where $\mathrm{Cu}$ status was normalized from baseline to visit 4 . Figure 5 shows the CCS concentrations in erythrocytes before and after $\mathrm{Cu}$ supplementation. There was no change in CCS between the patient's initial screening, baseline, and final visit.

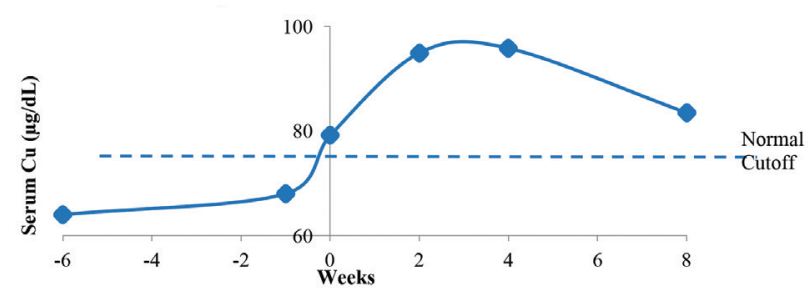

Figure 4. After 8 weeks of $8 \mathrm{mg} /$ day Cu gluconate supplementation, the patient began with $64 \mu \mathrm{g} / \mathrm{dL}$ of serum Cu and ended above a normal level at $83.4 \mu \mathrm{g} / \mathrm{dL}$. At the end of the intervention, serum Cu concentration was above the normal reference level.

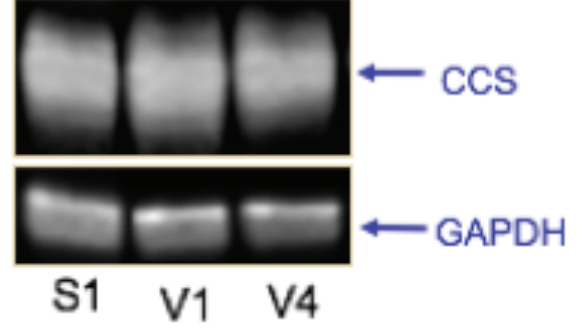

Figure 5. Patient supplemented with Cu gluconate showed no change in the concentration of CCS in erythrocytes.

Five patients were found to have Fe deficiency. Their serum $\mathrm{Cu}$ at screening averaged to be 145.8 $\mu \mathrm{g} / \mathrm{dL}$. Their ferritin concentrations increased from $5.1 \mu \mathrm{g} / \mathrm{L}$ to $18.76 \mu \mathrm{g} / \mathrm{L}$, visit 1 to visit 4 , respectively $(p=0.001)$. All patients had increased Fe status at the completion of the study. Figure 6 shows the changes in CCS concentrations in erythrocytes for patients who received Fe supplementation.

\section{DISCUSSION}

This study analyzed $\mathrm{Cu}$ status in normal and deficient patients following $\mathrm{Cu}$ and $\mathrm{Fe}$ supplementation. We evaluated whether a biomarker, called CCS, was associated with serum $\mathrm{Cu}$ concentrations, and how CCS responds to change in $\mathrm{Cu}$ status following $\mathrm{Fe}$ and $\mathrm{Cu}$ supplementation. Our study found no correlation between CCS concentrations in erythrocytes and serum $\mathrm{Cu}$. However, a significant increase was seen in CCS from visit 1 to visit 4 in patients who underwent $\mathrm{Fe}$ supplementation. CCS concentrations in the patient who received $\mathrm{Cu}$ supplementation did not change at any point during the study.

This study did not find a significant correlation between CCS concentrations in erythrocytes and serum $\mathrm{Cu}$, suggesting that CCS may not be a viable biomarker for $\mathrm{Cu}$ status in human subjects. This result was unexpected and contradicts previous research performed on rats where CCS was shown to be an effective biomarker in representing $\mathrm{Cu}$ status (West \& Prohaska, 2004). Additionally, it contradicts studies done on humans that showed CCS as a biomarker in assessing $\mathrm{Cu}$ toxicity (Araya et al., 2012). As far as we know, this was the first study to test CCS concentrations, as it relates to $\mathrm{Cu}$ deficiency in human subjects. CCS may respond differently in humans than we had expected from previous studies conducted on rats. Because we had a high CV both between and within assays for our Western blots, it is possible that the assay itself was not reliably 
A)

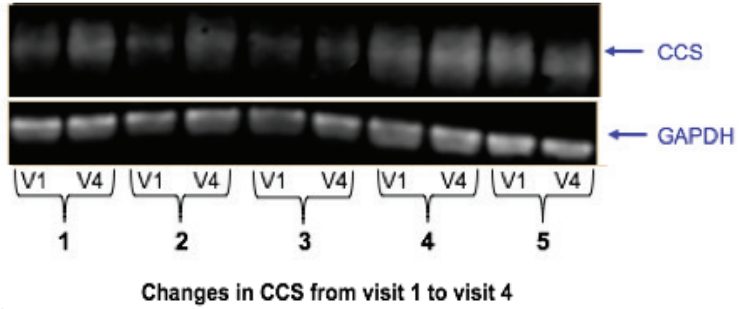

B)

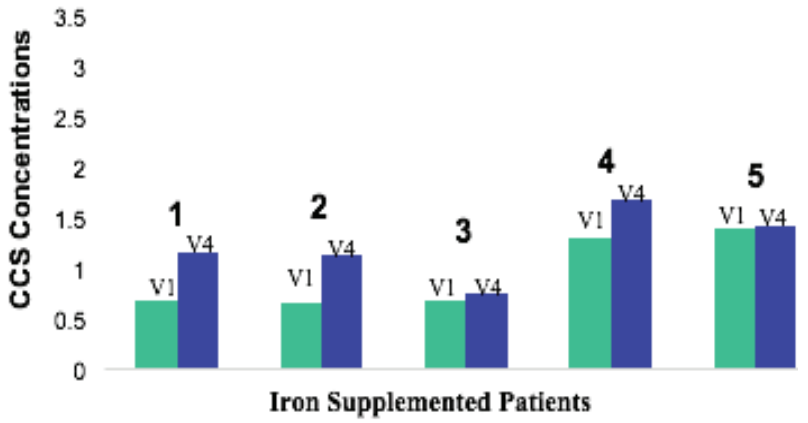

Figure 6. CCS between visits 1 and visits 4 significantly increase across all Fe supplemented patients $(p=0.046)$. (A). The image of the Western blot for Fe supplemented patients. GAPDH was used as the control across the patients. (B). All patients' CCS concentrations in erythrocytes increased after undergoing Fe supplementation. Mean [SEM] CCS for visit 1 was 0.958 [0.164], which increased to $1.247[0.154]$ at visit 4.

measuring CCS concentrations in the erythrocytes of human subjects. Further research should be conducted to assess the reliability of the methods used for this study.

The patient with $\mathrm{Cu}$ deficiency that we provided with high doses of $\mathrm{Cu}$ gluconate supplementation, $8 \mathrm{mg} /$ day for 8 weeks, had a normalized serum $\mathrm{Cu}$ status $(>70 \mathrm{mg} / \mathrm{dL})$ at the conclusion of the study. For this patient, $8 \mathrm{mg} /$ day was a sufficient amount of $\mathrm{Cu}$ supplementation to replete her $\mathrm{Cu}$ status by measurement of her serum $\mathrm{Cu}$. The $\mathrm{CCS}$ values for this patient did not appear to change from visit 1 to visit 4. It was surprising to only find one patient with $\mathrm{Cu}$ deficiency since our lab previously saw much higher incidence of $\mathrm{Cu}$ deficiency in the bariatric surgery population (Gletsu-Miller et al., 2012). Different geographical locations or a difference in diet may be reasons why we are seeing less incidence of $\mathrm{Cu}$ deficiency. Since $\mathrm{Cu}$ is affected by inflammation, high BMI in some of the patients may also be a factor that is affecting $\mathrm{Cu}$ status (Danzeisen et al., 2007). We suspect that dietary $\mathrm{Cu}$ is also associated with $\mathrm{Cu}$ status, but since we found only one patient with $\mathrm{Cu}$ deficiency, this remains to be determined. There is no evidence to suggest that blood loss through menstruation has an effect on $\mathrm{Cu}$ status. More patients with $\mathrm{Cu}$ deficiency would be needed to determine whether this supplementation treatment is sufficient to replete $\mathrm{Cu}$ status in patients who are $\mathrm{Cu}$-deficient, and to evaluate whether erythrocyte $\mathrm{CCS}$ responds to changes in $\mathrm{Cu}$ status following high-dose $\mathrm{Cu}$ supplementation.

In the other intervention, we had five patients who were enrolled to receive Fe supplementation. As we had expected, all the patients had a normalized Fe status at the conclusion of the study. A previous study in our lab analyzed dietary recall data of the subjects and showed that dietary Fe was associated with Fe status independent of the level of obesity, meaning patients who consumed less dietary Fe were more likely to be deficient (Mischler et al., 2015). Blood losses through menstruation or gastrointestinal problems are other areas that may affect $\mathrm{Fe}$ status in patients. The $\mathrm{Fe}$ supplement successfully normalized deficient patients.

There was a consistent increase in CCS from visit 1 to visit 4 in patients who were supplemented with Fe. Previous studies have shown that $\mathrm{Cu}$ status is low when Fe is high in animal models that consume high dietary Fe, and this study saw a similar trend in terms of erythrocyte CCS indicator of $\mathrm{Cu}$ status (Gulec \& Collins, 2014; Jung-Heun Ha et al., 2016). After receiving high doses of supplementary Fe for 8 weeks, patients had a significant increase in CCS. This implies that there is an interaction between $\mathrm{Fe}$ and CCS. Because no correlation was found between CCS and serum $\mathrm{Cu}$, we cannot determine if a change in $\mathrm{Cu}$ status in these patients is a potential reason for the change in CCS.

The present study is limited by its low statistical power, having only one patient supplemented with $\mathrm{Cu}$ and five patients supplemented with Fe. However, as the study is ongoing, the sample size will continue to increase. The study also only recruited females and all of the study subjects were Caucasian, so the study may not be generalizable to men or other races. In addition, we do not know what the serum $\mathrm{Cu}$ concentrations are for those enrolled in the Fe supplementation study. We did not record where patients were in their menstrual cycle at the time blood draws were taken. This would have an effect on Fe status, but there is no evidence to suggest that the menstrual cycle affects $\mathrm{Cu}$ status. We are actively working to obtain those values to explore how 
serum $\mathrm{Cu}$ may have changed compared to erythrocyte $\mathrm{CCS}$ in reaction to high doses of Fe supplementation.

While this study did not find a significant association between $\mathrm{CCS}$ in erythrocytes and serum $\mathrm{Cu}$ in human subjects, we did find a significant increase in CCS from visit 1 to visit 4 in patients who received high doses of Fe supplementation. We were also able to replete the $\mathrm{Cu}$ status of the $\mathrm{Cu}$-deficient patient who took high doses of $\mathrm{Cu}$ supplementation, though the patient's erythrocyte CCS concentrations were unchanged. We will continue to screen for patients who have $\mathrm{Cu}$ or Fe deficiency and treat them with high doses or oral supplementation. We will also continue to explore associations between $\mathrm{CCS}$ in erythrocytes and serum $\mathrm{Cu}$ in patients who have undergone bariatric surgery. Future studies should explore dietary records collected and how that relates to $\mathrm{Cu}$ status. Because obesity is an inflammatory disease, future studies should investigate whether BMI and body weight of patients affects $\mathrm{Cu}$ status, since serum $\mathrm{Cu}$ is elevated during inflammation (Danzeisen et al., 2007). Future studies should also explore how age of patients may affect $\mathrm{Cu}$ status.

\section{ACKNOWLEDGMENTS}

We would like to thank our patients, and we would like to acknowledge funding from the Transdisciplinary Obesity Prevention Research Sciences (TOPRS) program and the International Copper Association.

\section{REFERENCES}

Adams, T. D., Davidson, L. E., Litwin, S. E., Kolotkin, R. L., LaMonte, M. J., Pendleton, R. C., ... Hunt, S. C. (2012). Health benefits of gastric bypass surgery after 6 years. Journal of the American Medical Association, 308(11), 1122-1131. http://dx.doi.org/10.1001/2012. jama.11164

Angrisani, L., Santonicola, A., Iovino, P., Formisano, G., Buchwald, H., \& Scopinaro, N. (2015). Bariatric surgery worldwide 2013. Obesity Surgery, 25(10), 1822-1832. http://dx.doi.org/10.1007/s11695-015-1657-z

Araya, M., Olivares, M., Pizarro, F., González, M., Speisky, H., \& Uauy, R. (2003). Copper exposure and potential biomarkers of copper metabolism. Biometals, 16(1), 199-204. http://dx.doi. org/10.1023/A:1020723117584

Araya, M., Andrews, M., Pizarro, F., \& Arredondo, M. (2012). Chaperones CCS, ATOX and COXIV responses to copper supplementation in healthy adults. Biometals, 25(2), 383-391. http://dx.doi.org/10.1007/s10534-0119511-9

Buchwald, H., \& Oien, D. M. (2013). Metabolic/bariatric surgery worldwide 2011. Obesity Surgery, 23(4), 427-436. http://dx.doi.org/10.1007/s11695-012-0864-0

Christou, N. V., Sampalis, J. S., Liberman, M., Look, D., Auger, S., McLean, A. P. H., \& MacLean, L. D. (2004). Surgery decreases long-term mortality, morbidity, and health care use in morbidly obese patients. Annals of
Surgery, 240(3), 416-423; discussion 423-424. http:// dx.doi.org/10.1097/01.sla.0000137343.63376.19

Ciangura, C., Nocca, D., \& Lindecker, V. (2010). Guidelines for clinical practice for bariatric surgery. La Presse Médicale, 39(9), 953-959. http://dx.doi.org/10.1016/j. lpm.2010.03.025

Clements, R. H., Katasani, V. G., Palepu, R., Leeth, R. R., Leath, T. D., Roy, B. P., \& Vickers, S. M. (2006). Incidence of vitamin deficiency after laparoscopic Rouxen-Y gastric bypass in a university hospital setting. American Journal of Surgery, 72(12), 1196-1202; discussion 1203-1204.

Collins, J. F., Franck, C. A., Kowdley, K. V., \& Ghishan, F. K. (2005). Identification of differentially expressed genes in response to dietary iron deprivation in rat duodenum. American Journal of Gastrointestinal and Liver Physiology, 288(5), G964-G971. http://dx.doi. org/10.1152/ajpgi.00489.2004

Culotta, V. C., Klomp, L. W. J., Strain, J., Casareno, R. L. B., Krems, B. \& Gitlin, J. D. (1997). The copper chaperone for superoxide dismutase. Journal of Biological Chemistry, 272(38), 23469-23472. http://dx.doi. org/10.1074/jbc.272.38.23469

Danzeisen, R., Arayaa, M., Harrisona, B., Keena, C., Solioza, M., Thielea, D., \& McArdlea, H. J. (2007). How reliable and robust are current biomarkers for copper status? British Journal of Nutrition, 98(4), 676-683. http://dx.doi.org/10.1017/S0007114507798951

Dixon, J. B., O’Brien, P. E., Playfair, J., Chapman, L., Schnachter, L. M., Skinner, S., . . A Anderson, M. (2008). Adjustable gastric banding and conventional therapy for type 2 diabetes: A randomized controlled trial. Journal of the American Medical Association, 299(3), 316-323. http://dx.doi.org/10.1001/jama.299.3.316

Fox, P. L. (2003). The copper-iron chronicles: The story of an intimate relationship. Biometals, 16(1), 9-40. http:// dx.doi.org/10.1023/A:1020799512190

Finkelstein, E. A., Khavjou, O. A., Thompson, H., Trogdon, J. G., Pan, L., Sherry, B., \& Deitz, W. (2012). Obesity and severe obesity forecasts through 2030. American Journal of Preventative Medicine, 42(6), 563-570. http://dx.doi.org/10.1016/j.amepre.2011.10.026

Flegal, K. M., Carroll, M. D., Kit, B. K., \& Ogden, C. L. (2012). Prevalence of obesity and trends in the distribution of body mass index among US adults, 1999-2010. Journal of the American Medical Association, 307(5), 491-497. http://dx.doi.org/10.1001/jama.2012.39

Gasteyger, C., Suter, M., Gaillard, R. C., \& Giusti, V. (2008). Nutritional deficiencies after Roux-en-Y gastric bypass for morbid obesity often cannot be prevented by standard multivitamin supplementation. American Journal of Clinical Nutrition, 87(5), 1128-1133.

Gletsu-Miller, N. \& Wright, B. N. (2013). Mineral malnutrition following bariatric surgery. Advances in Nutrition, 4(5), 506-517. http://dx.doi.org/10.3945/ an.113.004341

Gletsu-Miller, N., Broderius, M., Frediani, J. K., Zhao, V. M., Griffith, D. P., Davis Jr., S. S., . . Ziegler, T. R. (2012). Incidence and prevalence of copper deficiency following roux-en-y gastric bypass surgery. International Journal of Obesity (London), 36(3), 328-335. http://dx.doi. org/10.1038/ijo.2011.159

Grant, F. K., Martorell, R., Fores-Ayala, R., Cole, C. R., Ruth, L. J. Ramakrishnan, U., \& Suchdev, P. S. (2012). Comparison of indicators of iron deficiency in Kenyan children. American Journal of Clinical Nutrition, 95(5), 1231-1237. http://dx.doi.org/10.3945/ajen.111.029900 
Griffith, D. P., Lift, D. A., Ziegler, T. R., Esper, G. J., \& Winton, E. F. (2009). Acquired copper deficiency: A potentially serious and preventable complication following gastric bypass surgery. Obesity (Silver Spring), 17(4), 827-831. http://dx.doi.org/10.1038/oby.2008.614

Gulec, S., \& Collins, J. F. (2014). Molecular mediators governing iron-copper interactions. Annual Review of Nutrition, 34, 95116. http://dx.doi.org/10.1146/annurev-nutr-071812-161215

Haremaki, T., Fraser, S. T., Kuo, Y.-M., Baron, M. H., \& Weinstein, D. C. (2007). Vertebrate Ctrl coordinates morphogenesis and progenitor cell fate and regulates embryonic stem cell differentiation. Proceedings of the National Academy of Sciences (USA), 104(29), 1202912034. http://dx.doi.org/10.1073/pnas.0701413104

Hellman, N. E., \& Gitlin, J. D. (2002). Ceruloplasmin metabolism and function. Annual Review of Nutrition, 22, 439-458. http://dx.doi.org/10.1146/annurev.nutr.22.012502.114457

Holmberg, C. G., \& Laurell, C. B. (1947). Investigations in serum copper; nature of serum copper and its relation to the iron-binding protein in human serum. Acta Chemical Scandinavica, 1(10), 944-950. http://dx.doi.org/10.3891/acta. chem.scand.01-0944

Iskandar, M., Swist, E., Trick, K. D., Wang, B., L'Abbé, $\&$ Bertinato, J. (2005). Copper chaperone for $\mathrm{Cu} / \mathrm{Zn}$ superoxide dismutase is a sensitive biomarker of mild copper deficiency induced by moderately high intakes of zinc. Nutrition Journal, 4, 35. http://dx.doi. org/10.1186/1475-2891-4-35

Jensen, M. D., Ryan, D. H., Apovian, C. M., Ard, J. D., Comuzzie, A. G., Donato, K. A., . . Yanovski, S. Z. (2014). 2013 AHA/ACC/TOS guideline for the management of overweight and obesity in adults: A report of the American College of Cardiology/American Heart Association Task Force on Practice Guidelines and the Obesity Society. Journal of the American College of Cardiology, 63(25 Pt B), 2985-3023. http://dx.doi.org/10.1016/j.jacc.2013.11.004

Jung-Heun Ha, C. D., Zhao, S., Wang, X., Flores, S. R., \& Collins, J. F. (2016). High dietary iron intake impairs growth and causes copper deficiency in Sprague-Dawley rats. The FASEB Journal, 30(1), supp. 292.4.

Lassi, K. C., \& Prohaska, J. R. (2012). Erythrocyte copper chaperone for superoxide dismutase is increased following marginal copper deficiency in adult and postweanling mice. Journal of Nutrition, 142(2), 292-297. http://dx.doi. org/10.3945/jn.111.150755

MacLean, L. D., Rhode, B. M., \& Nohr, C. W. (2000). Late outcome of isolated gastric bypass. Annals of Surgery, 231(4), 524-528. http://dx.doi.org/10.1097/00000658200004000-00011
Mason, K. E. (1979). A conspectus of research on copper metabolism and requirements of man. Journal of Nutrition, 109(11), 1979-2066.

Mischler, R. A., Armah, S. M., Wright, B. N., Mattar, S. G., Rosen, A. D., \& Gletsu-Miller, N. (2015). Influence of diet and supplements on iron status after gastric bypass surgery. Surgery for Obesity and Related Diseases, 12(3), 651-658. http://dx.doi.og/10.1016/j.soard.2015.09.007

Schauer, P. R., Bhatt, D. L., Kirwan, J. P., Wolski, K., Brethauer, S. A., Navaneethan, S. D., . . Kashyap, S. R. (2014). Bariatric surgery versus intensive medical therapy for diabetes-3-year outcomes. New England Journal of Medicine, 370(21), 2002-2013. http://dx.doi.org/10.1056/ NEJMoa1401329

Schowalter, M., Benecke, A., Lager, C., Heimbucher, J., Bueter, M., Thalheimer, A., . . . Faller, H. (2008). Changes in depression following gastric banding: A 5- to 7-year prospective study. Obesity Surgery, 18(3), 314-320. http:// dx.doi.org/10.1007/s11695-007-9316-7

Sjöström, L., Lindroos, A.-K., Peltonen, M., Torgerson, J., Bouchard, C., Carlsson, B., . . . Wedel, H. (2004). Lifestyle, diabetes, and cardiovascular risk factors 10 years after bariatric surgery. New England Journal of Medicine, 351(26), 2683-2693. http://dx.doi.org/10.1056/NEJMoa035622

Sjöström, L., Narbro, K., Sjöström, C. D., Karason, K., Larsson, B., Wedel, H., . . Carlsson, L. M. S. (2007). Effects of bariatric surgery on mortality in Swedish obese subjects. New England Journal of Medicine, 357(8), 741-752. http:// dx.doi.org/10.1056/NEJMoa066254

Sjöström, L., Peltonen, M., Jacobson, J., Sjöström, C. D., Karason, K., Wedel, H., ... Carlsson, L. M. S. (2012). Bariatric surgery and long-term cardiovascular events. Journal of the American Medical Association, 307(1), 56-65. http://dx.doi.org/10.1001/jama.2011.1914

Trumbo, P., Yates, A. A., Schlicker, S., \& Poos, M. (2001). Dietary reference intakes: Vitamin A, vitamin K, arsenic, boron, chromium, copper, iodine, iron, manganese, molybdenum, nickel, silicon, vanadium, and zinc. Journal of the American Dietetic Association, 101(3), 294-301. http://dx.doi. org/10.1016/S0002-8223(01)00078-5

West, E. C., \& Prohaska, J. R. (2004). Cu, Zn-superoxide dismutase is lower and copper chaperone CCS is higher in erythrocytes of copper-deficient rats and mice. Experimental Biology and Medicine (Maywood), 229(8), 756-64.

World Health Organization (WHO). (2016). Obesity. http://www. who.int/topics/obesity/en/. 